\title{
Assessment of antimicrobial activity in vitro of ethanolic extracts of Banisteriopsis anisandra (A. Juss.) B. Gates (Malpighiaceae)
}

PÁDUA, M.S. ${ }^{1 ;}$ MENDES-COSTA, M.C. ${ }^{2}$; FERREIRA, J.M.S. ${ }^{3}$; MAGALHÃES, J.C..$^{4}$ CASTRO, A.H.F. ${ }^{3^{*}}$ ${ }^{1}$ Universidade Federal de Lavras, 37200-000, Lavras, MG, Brasil. ${ }^{2}$ Centro Universitário de Lavras, 37200-000, Lavras, MG, Brasil. ${ }^{3}$ Universidade Federal de São João del Rei, Campus Centro-Oeste Dona Lindu, 35501-290, Divinópolis, MG, Brasil. ${ }^{4}$ Universidade Federal de São João Del-Rei, Campus Alto Paraopeba, 36420-000, Ouro Branco, MG, Brasil. *acastro@ufsj.edu.br

\begin{abstract}
The aim of this study was to evaluate the antimicrobial activity in vitro of ethanolic extracts of Banisteriopsis anisandra. Tests were performed using the extracts overlay method in the culture medium for phytopathogenic fungi Rhizoctonia solani and Fusarium oxysporum, and disk diffusion for the microorganisms Staphylococcus aureus and Candida albicans. Ethanolic extracts from leaves were prepared by maceration (extract I) and decoction (extract II) at 430.0, 215.0 and $107.5 \mathrm{mg} / \mathrm{mL}$. The growth inhibition of $R$. solani and $F$. oxysporum was determined by calculating the mycelia growth speed rate (MGSR) and, in relation C. albicans and S. aureus, it was determined by measuring the inhibition halos. Extracts that caused significant inhibition were also tested at $86.0,64.5,43.0$ and $21.5 \mathrm{mg} / \mathrm{mL}$ for $C$. albicans and $S$. aureus. Both extracts showed inhibitory activity on the microorganisms studied. Rizoctonia solani showed lower MGSR in the presence of extract II $(107.5 \mathrm{mg} / \mathrm{mL})$ and Fusarium oxysporum showed slight MGSR reduction in the presence of extract I $(107.5 \mathrm{mg} / \mathrm{mL})$ and II $(107.5$ and $215 \mathrm{mg} / \mathrm{mL})$. Ethanolic extracts I and II inhibited the growth of $C$. albicans, with the highest rates of inhibition observed in the presence of extract II $(215.0 \mathrm{mg} / \mathrm{mL})$. For $S$. aureus, the highest inhibitory activity was observed in the presence of ethanolic extract II, prepared by decoction at $430.0 \mathrm{mg} / \mathrm{mL}$. Results showed a promising antimicrobial activity of extracts of $B$. anisandra, which may contribute to further studies leading to a future development of medicines to treat human and plant diseases caused by these organisms.
\end{abstract}

Keywords: Banisteriopsis anisandra, antimicrobial activity, ethanolic extracts.

RESUMO: Avaliação da atividade antimicrobiana in vitro de extratos etanólicos de Banisteriopsis anisandra (A. Juss.) B. Gates (Malpighiaceae). O objetivo deste estudo foi avaliar a atividade antimicrobiana in vitro de extratos etanólicos de Banisteriopsis anisandra. Os testes foram realizados utilizando o método de sobreposição de extratos em meio de cultura para fungos fitopatogênicos Rhizoctonia solani e Fusarium oxysporum e de difusão em disco para os microrganismos Staphylococcus aureus e Candida albicans. Foram testados de extratos etanólicos de folhas preparados por maceração (extrato I) e decocção (extrato II), nas concentrações de 430,0; 215,0 e $107,5 \mathrm{mg} / \mathrm{mL}$. A inibição do crescimento de $R$. solani e F. oxysporum foi determinada pelo cálculo do índice de velocidade de crescimento micelial (IVCM) e de C. albicans e $S$. aureus, por meio da medida da halos de inibição. Os extratos que causaram inibição significativa também foram testados nas concentrações de 86,0; 64,5; 43,0 e $21,5 \mathrm{mg} / \mathrm{mL}$ para $C$. albicans e $S$. aureus. Ambos os extratos mostraram atividade inibitória sobre os microrganismos estudados. Rizoctonia solani apresentou menor IVCM na presença do extrato II (107,5 mg/mL) e Fusarium oxysporum apresentou discreta redução no IVCM na presença do extrato I (107,5 mg/mL) e II (107,5 e $215 \mathrm{mg} / \mathrm{mL})$. Extratos etanólicos I e II inibiram o crescimento de $C$. albicans, com as maiores taxas de inibição observadas na presença do extrato II $(215,0 \mathrm{mg} / \mathrm{mL})$. Para $S$. aureus a maior atividade inibitória foi observada na presença do extrato II, na concentração de $430 \mathrm{mg} / \mathrm{mL}$. Os resultados mostraram promissora atividade antimicrobiana de extratos de $B$. anisandra, o que pode contribuir para estudos futuros visando o desenvolvimento de medicamentos para doenças humanas e de plantas causadas por estes microrganismos.

Palavras-chave: Banisteriopsis anisandra, atividade antimicrobiana, extratos etanólico.

Recebido para publicação em 12/09/2011

Aceito para publicação em 23/01/2013

Rev. Bras. PI. Med., Campinas, v.15, n.3, p.431-437, 2013. 


\section{INTRODUCTION}

According to the World Health Organization (World Health Organization, 2011), 65 to $80 \%$ of the population of developing countries make use of plants as a therapeutic alternative. However, few have been scientifically studied regarding the quality, safety, and efficacy of their compounds (Calixto, 2005).

The search for technologies to develop new drugs is a promising strategy in this field, as it allows the exploration of new classes of natural and/or synthetic molecules able to neutralize or damage any target-pathogen (Heinemann et al., 2000). This search has increased due to numerous recent reports showing the emergence of microorganisms with different degrees of resistance to conventional antibiotics, and even to those of the last generation (Dienstmann, 2010). On example is Staphylococcus aureus, strain now endemic to Brazil, which is resistant to methicillin (MRSA) and to virtually all antibiotics except vancomycin (Rossi, 2011). Moreover, the clinical relevance of fungal opportunistic infections has grown at an alarming rate since the second half of the 20th century, evident in the increase of individuals infected with HIV, transplant patients and cancer patients (Clark \& Hajjeh, 2002). Some examples of opportunistic and non-opportunistic microorganisms are Candida sp., Aspergillus sp., Cryptococcus neoformans, and Mucor (Kirchner et al., 2010).

From an the agricultural point of view, pathogenic fungi such as Fusarium oxysporum and Rizoctonia solanum are important because of the losses they causes in agriculture, and also due to their resistance to commonly used antifungal agents. Fungicides procymidone, captan and pentachlorinatednitrobenzene used together are not efficient in controlling diseases caused by Rizoctonia solani in cotton and Fusarium oxysporum is resistant to thiabendazole (Goulart., 2008). According to Dambolena et al. (2010), the genus Fusarium produces mycotoxins, affecting crops in fields and storage of grains, resulting in the rejection of the seeds on the market. Fusarium oxysporum causes a reduction of yield and grain quality and is responsible for vascular wilt disease in tomato crops. Rizoctonia solani attacks cotton seeds and seedlings causing pre-and post-emergence damping-off (Goulart, 2005). The most common treatment of these infectious diseases involves azoles and polyenes macrolide, which are limited in their spectrum of activity due to their adverse effects (Helmerhorst et al., 1999).

Thus, the search for new alternatives to control of microorganisms assumes considerable importance, and plant extracts have become an important resource (Bertucci, 2009; Regasini,
2009). Banisteriopsis anisandra is species with pantropical distribution of which little is known. According to Freitas (2010), the species is commonly used for topical treatment of fungal infections, and a hydrocarbon mixture, palmitic acid, lupeol and kercetin 3-O-ramnosid was isolated from leaves. The Genus Banisteriopsis has been quoted extensively in the literature with regards to its medicinal potential, with antimicrobial and anti-inflammatory activities already having been characterized. Antiinflammatory action have been described for the extract of $B$. argyrophylla employed in ovarian hemorrhage and nephritis; $B$. campestris is a species used as a diuretic; and $B$. megaphylla, popularly known as silver vine, has antipyretic activity, is an astringent, and can be used in treatments of lung disease (Rodrigues \& Carvalho, 2001). According to Samoylenko et al. (2010), B. caapi can be used against neurodegenerative diseases and to treat Parkinson's disease.

Due to the few studies related to antibacterial and antifungal activities of $B$. anisandra and the genus importance, this study aimed to evaluate the in vitro antimicrobial activity of ethanolic extracts of $B$. anisandra against the microorganisms Rizoctonia solani, Fusarium oxysporum, Candida albicans and Staphylococcus aureus.

\section{MATERIAL AND METHODS}

\section{Plant material, preparation of extracts and microorganisms used}

The experiments were conducted between March and October 2008 at the Laboratory of Biology, University Center of Lavras (UNILAVRAS) in Lavras, Minas Gerais, Brazil. Leaves of Banisteriopsis anisandra (A. Juss.) B. Gates were collected in March 2008, in the Ecological Reserve Boqueirão belonging to UNILAVRAS, located in the city of Ingaí, southern Minas Gerais at $951 \mathrm{~m}$ altitude, $21^{\circ} 24^{\prime} 04^{\prime \prime} \mathrm{S}$ latitude and $44^{\circ} 55^{\prime} 02^{\prime \prime}$ W GRW longitude. Samples of plant material were collected and herborized. The voucher (n. 2397) was deposited in the Herbarium LUNA, Lavras University Center. After collection, leaves were selected, sectioned, and dried in an oven at $40{ }^{\circ} \mathrm{C}$ with forced ventilation until reaching constant weight. Subsequently, samples were crushed in a knife mill and stored in vials in the dark until being ready to use.

Two types of extracts, ethanolic extracts I and II, were prepared according to traditional knowledge related for Rodrigues e Carvalho (2001). For extract I, 30 grams of dried plant material was subjected to maceration in $70 \mathrm{~mL}$ of $80 \%$ ethanol $(\mathrm{v} / \mathrm{v})$ under constant stirring for 10 days. The extract 
was filtered and adjusted to $70 \mathrm{~mL}$. Extract II was prepared by decoction of 30 grams of dried plant material with $70 \mathrm{~mL}$ of $80 \%$ ethanol $(\mathrm{v} / \mathrm{v})$ for 10 minutes. The extract was filtered and adjusted to 70 $\mathrm{mL}$ with $80 \%$ ethanol. Ethanol extracts I and II were placed in amber vial in the dark.

Extracts were tested for Staphylococcus aureus (ATCC 6538), Candida albicans (ATCC 10231), and the pathogenic fungi Fusarium oxysporum (CML 0288) and Rhyzotonia solani (CML 0248). The pathogenic fungi were provided by Prof. Ludwig Heinrich Pfenning, Department of Phytopathology, Federal University of Lavras.

\section{Evaluation of antimicrobial activity Rhyzotonia solani and Fusarium oxysporum Rhyzotonia solani and Fusarium oxysporum} were cultured in potato dextrose agar (PDA) in germination chamber environment, with a 12-hour photoperiod at $22^{\circ} \mathrm{C}$. From the aerial hyphae of these fungi, a $0.5 \mathrm{~cm}$ fragment was isolated and inoculated in the center of a Petri dish containing a $20-\mathrm{mL}$ culture medium BDA. $100 \mu \mathrm{L}$ of ethanolic extracts I and II at $107.5,215.0$, and $430.0 \mathrm{mg} / \mathrm{mL}$ were used. Negative controls consisted of a PDA medium containing $80 \%$ ethanol and a PDA medium containing fungi tested in the absence of ethanol extracts, and the azole antifungal ketoconazole $(2 \mathrm{mg} / \mathrm{mL})$ was used as a positive control. The antimicrobial activity against fungi $R$. solani and $F$. oxysporum was assessed by measuring the mycelium diameter for eight days after inoculation in a PDA medium and these values were used to determine the Mycelia Growth Speed Rate (MGSR) (Maguire, 1962, adapted by Oliveira, 1991): MGRS $=\mathrm{S}(\mathrm{D}-\mathrm{Da}) / \mathrm{N}$

where: $M G S R=$ Mycelia Growth Speed Rate, $\mathrm{D}=$ current average, $\mathrm{Da}=$ Average diameter of the previous day, and $\mathrm{N}=$ Number of days after inoculation.

Tests were performed in triplicate and the results were expressed as mean \pm standard deviation of MGSR obtained.

\section{Candida albicans}

The antimicrobial activity of Candida albicans was evaluated according to the diffusion plate method described by Bauer et al. (1966) with some modifications. The yeast was grown in a potato dextrose agar (PDA) culture medium for 24 hours and transferred to a saline solution $(0.85 \%)$ so that turbidity matched 0.5 in the MacFarland scale. Yeast suspension $(100 \mu \mathrm{L})$ was mixed in a $20-\mathrm{mL}$ PDA medium and after solidification qualitative filter paper discs of $6 \mathrm{~mm}$ in diameter were added, and 20 $\mu \mathrm{L}$ ethanol extracts of I and II at 107.5, 215.0, and $430.0 \mathrm{mg} / \mathrm{mL}$ were pipetted. Extracts that caused significant inhibition were also tested at 86.0, 64.5,
43.0 , and $21.5 \mathrm{mg} / \mathrm{mL}$ to determining the minimum inhibitory concentration (MIC). Negative controls consisted a PDA medium containing $80 \%$ ethanol and a PDA medium containing $C$. albicans in the absence of ethanol extracts. Ketoconazole (2mg/ $\mathrm{mL}$ ) was used as positive control. Cultures were incubated at $25 \pm 1^{\circ} \mathrm{C}$, monitored for 96 hours and the diameters of inhibition halos were measured daily during this period.

\section{Staphylococcus aureus}

The evaluation of antimicrobial activity of Staphylococcus aureus was performed by the disk diffusion method described by Bauer et al. (1966). Colonies previously grown in a BHI (Brain Heart Infusion) medium for 24 hours were transferred to a saline solution $(0.85 \%)$, so that the turbidity matched 0.5 in the MacFarland scale, which is equivalent to an inoculum of $1.5 \times 10^{8}$ colonyforming units (CFU) for each $1 \mathrm{~mL}$. Bacterial cultures $(100 \mu \mathrm{L})$ were inoculated in Mueller Hinton Agar on which qualitative filter paper discs with $6 \mathrm{~mm}$ in diameter were deposited, then impregnated with $20 \mu \mathrm{L}$ ethanolic extracts I and II at 107.5, 215.0, and $430.0 \mathrm{mg} / \mathrm{mL}$. Extracts that caused significant inhibition were also tested at 86.0, 64.5, 43.0, and $21.5 \mathrm{mg} / \mathrm{mL}$ to determine the minimum inhibitory concentration (MIC). Negative controls consisted of a $\mathrm{BHI}$ medium containing $80 \%$ ethanol and a $\mathrm{BHI}$ medium containing $S$. aureus in the absence of ethanolic extracts, and tetracycline was used as positive control $(30 \mathrm{mg} / \mathrm{mL})$. Plates were incubated at $35 \pm 1{ }^{\circ} \mathrm{C}$ for 24 hours. Tests were performed in triplicate and the results expressed as mean \pm standard deviation of the inhibition halos formed.

\section{Analysis \\ Experimental Design and Statistical}

The experimental design was completely randomized and consisted of two extracts (I and II), three concentrations of each extract, four microorganisms, and four repetitions, in a total of 96 plots. The Tukey test at $5 \%$ probability was used to compare contrasts among means. Data analysis was performed using the software Sisvar 5.0 (Ferreira, 2008).

\section{RESULTS AND DISCUSSION}

Extracts I and II (107.5 mg/mL) caused significant reduction in MGRS of both fungi when compared to control treatments and extract II (107.5 $\mathrm{mg} / \mathrm{mL}$ ), and promoted significant reduction in growth of $R$. solani $(p<0.05)$ (Table 1$)$. F. oxysporum had lower mycelia growth in the presence of extracts I and II at $107.5 \mathrm{mg} / \mathrm{mL}$. Mycelia growth of $R$. solani and $F$. oxysporum was completely inhibited 
TABLE 1. Mycelia growth speed rate (MGSR) $(\mathrm{mm})$ in the presence of extracts I and II (Mean \pm mean standard error). Means followed by same letter do not differ among themselves by the Tukey test at $5 \%$ probability.

\begin{tabular}{ccc}
\hline Extract concentrations & $\boldsymbol{R}$. solani & F. oxysporum \\
\hline (C-) 1 & $10.80 \pm 0.19 \mathrm{a}$ & $12.10 \pm 0.13 \mathrm{a}$ \\
(C) 2 & $11.10 \pm 0.13 \mathrm{a}$ & $10.40 \pm 0.21 \mathrm{a}$ \\
Ketoconazole $(\mathrm{C}+)$ & $0 \mathrm{c}$ & $0 \mathrm{c}$ \\
E I $(107.5 \mathrm{mg} / \mathrm{mL})$ & $11.80 \pm 0.03 \mathrm{a}$ & $8.70 \pm 0.07 \mathrm{~b}$ \\
E I $(215 \mathrm{mg} / \mathrm{mL})$ & $8.80 \pm 0.10 \mathrm{a}$ & $10.00 \pm 0.21 \mathrm{a}$ \\
E I $(430 \mathrm{mg} / \mathrm{mL})$ & $9.60 \pm 0.11 \mathrm{a}$ & $10.30 \pm 0.17 \mathrm{a}$ \\
E II $(107.5 \mathrm{mg} / \mathrm{mL})$ & $5.10 \pm 0.17 \mathrm{~b}$ & $9.00 \pm 0.17 \mathrm{~b}$ \\
E II $(215 \mathrm{mg} / \mathrm{mL})$ & $11.10 \pm 0.11 \mathrm{a}$ & $9.80 \pm 0.25 \mathrm{a}$ \\
E II $(430 \mathrm{mg} / \mathrm{mL})$ & $8.30 \pm 0.27 \mathrm{a}$ & $10.40 \pm 0.21 \mathrm{a}$ \\
\hline
\end{tabular}

(C-) 1= negative control (ADP medium+ fungus); (C-) 2= negative control (ADP medium + fungus + ethanol diluent agent); (C+) positive control (Ketoconazole); E I= extract I; E II= extract II.

by ketoconazole used as positive control. The residual alcohol content in ethanol extracts showed no interference with antimicrobial activity against $R$. solani; however F. oxysporum showed a small sensitivity to the solvent used.

According to Fenille and Souza (1999), the antifungal activity observed for $R$. solani is promising, thought the effective chemical control of disease caused by this fungus is still inconsistent. Our results indicate that less concentrated extracts are more effective in controlling the growth of $R$. solani and $F$ oxysporum and suggest the use of extracts prepared by decoction, an extraction method that is a faster, cheaper and, simpler to perform when compared with the steeping method used.

The inhibiting of growth of pathogenic fungi by ethanol extracts and essential oils by medicinal species has been described in previous studies. Cunico et al. (2002) evaluated the activity of crude ethanolic extract from Maytenus ilicifolia leaves against $F$. oxysporum and reported low levels of mycelia growth in the presence of low concentrations of "espinheira santa" extract used. Crude ethanol extracts from stems and leaves of Aster lanceolatus also promoted inhibition in mycelia growth of $F$. oxysporum at $0.57 \mathrm{mg} / \mathrm{mL}$ (Dias et al., 2006). Silva et al. (2005) reported that the extract of sucupira (Pterodon emarginatus) inhibited mycelia growth of $F$. oxysporum and $R$. solani in various concentrations tested. Costa et al. (2011), using essential oil of Syzygium aromaticum $(1.5 \mathrm{mg} / \mathrm{mL})$, demonstrated complete inhibition of fungal growth of $R$. solani and $F$. oxysporum. The growth of $F$. oxysporum and $R$. Solanum has also been successfully inhibited by the essential oils of Croton cajucara and Silene armeria (Bajpai et al., 2008). These results demonstrate the importance of assessing the effect of $B$. anisandra essential oil in search of a fungicide, in addition to classifying its fungistatic properties, as noted in the extracts tested.

Results for $C$. albicans indicate that extracts I and II at the different concentrations used promoted a significant reduction in growth $(p<0.05)$, with the inhibition caused by extract II $(215.0 \mathrm{mg} / \mathrm{mL})$ statistically similar to the positive control used, represented by ketoconazole (Figure 1). Both extracts were able to promote strong growth inhibition of $C$. albicans from the concentration of $86.0 \mathrm{mg} / \mathrm{mL}$. Ethanol used as a negative control did not cause growth inhibition of $C$. albicans.

Results obtained for $C$. albicans corroborate those found by Freitas (2010) in studies on aqueous extracts from $B$. anisandra leaves, which showed high sensitivity to minimum inhibitory concentration of $31.25 \mathrm{mg} / \mathrm{mL}$. Satisfactory results with regard to growth inhibition of $C$. albicans were also observed by Alves et al. (2006), who found that pure ethanol extract from Psidium guajava leaves produced a growth inhibition halo of $22 \mathrm{~mm}$, while ShinobuMesquita et al. (2011), using the hydroalcoholic extract of Curcuma zedoaria at 1.95 and $15.63 \mathrm{mg} /$ $\mathrm{mL}$, observed inhibitions at the same magnitude. However, crude ethanol extract from Lippia alba (Aguiar et al., 2008), Gochnatia polymorpha (Stefanello et al., 2006), and Cymbopogum citratus (Schuck et al., 2001) leaves showed no significant inhibitory activity in C. albicans regardless of the concentration used.

For S. aureus, bolth extract I and extract II showed significant growth inhibition of $S$. aureus regardless of concentrations originally used $(p<0.05)$ (Figure 2). A visible dose-dependent effect for the concentrations studied was observed, with inhibition being much higher than that presented by tetracycline used as positive control. S. aureus was not sensitive to the residual effect of $80 \%$ ethanol 


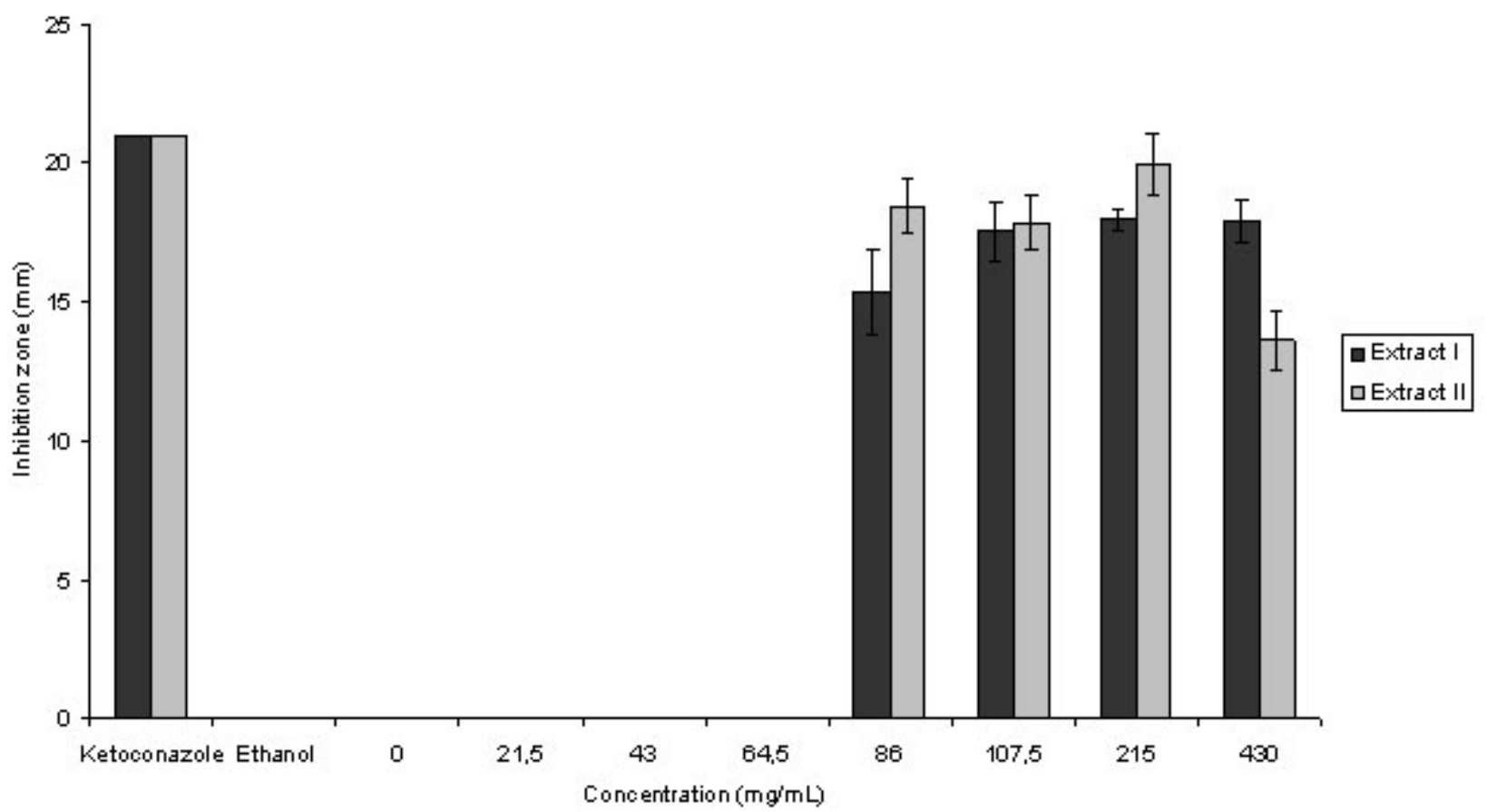

FIGURE 1. Activity of ethanol extracts of $B$. anisandra against $C$. albicans. Results are expressed as mean diameter $(\mathrm{mm})$ of the inhibition halos \pm standard deviation.

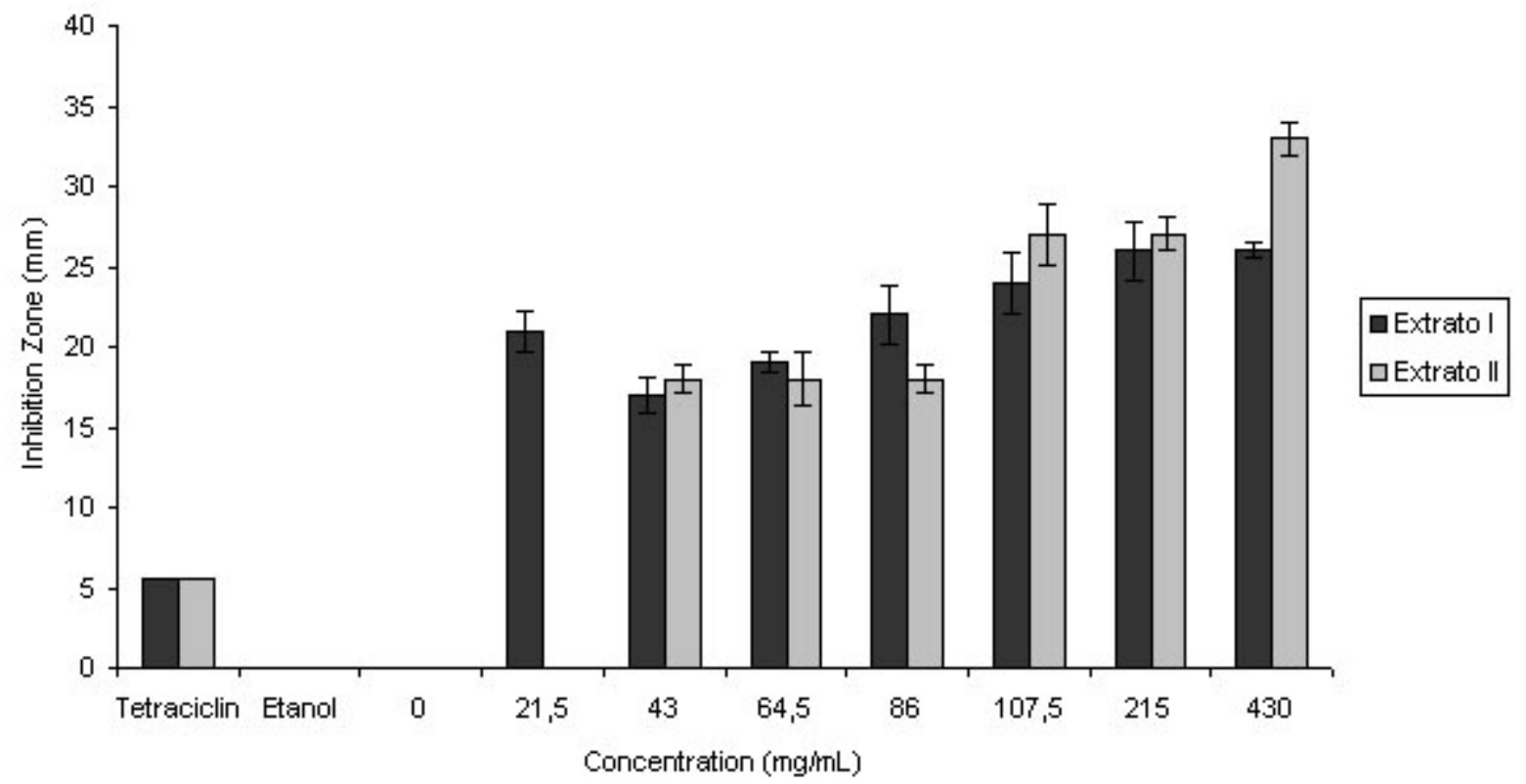

FIGURE 2. Activity of ethanol extracts from $B$. anisandra against $S$. aureus. Results are expressed as mean diameter $(\mathrm{mm})$ of inhibition halos \pm standard deviation.

used in the preparation of extracts.

Figure 2 shows that most inhibitory activity was obtained in the presence of ethanol extract II at $430.0 \mathrm{mg} / \mathrm{mL}$ with halos reaching $33.5 \mathrm{~mm}$. However, extract I was able to promote a significant inhibition of bacterial growth in a much lower concentration of $21.5 \mathrm{mg} / \mathrm{mL}$ producing halos with $22 \mathrm{~mm}$ in diameter. These results were superior to those obtained by Freitas (2010), who did not observe growth inhibition of $S$. aureus ATCC 29212 when testing the aqueous extract from leaves of $B$. anisandra prepared by steeping at $100 \mathrm{mg} / \mathrm{mL}$. Frias et al. (2011), when evaluating the antimicrobial activity of concentrated crude extracts from leaves of $B$. anisandra prepared by maceration at $1 \mathrm{mg} / \mathrm{mL}$ with hexane, chloroform, ethyl acetate, and methanol, did not observe significant inhibition in the growth of $S$. aureus and other bacteria tested with these extracts. In addition to $B$. anisandra, ethanolic extracts from other medicinal species showed promising antibacterial activity 
against S. aureus, such as Lippia alba (Aguiar et al., 2008), Anacardium occidentale, Stryphnodendron adstringens, Bixa orellana, Eugenia uniflora L., Psidium guajava, Mimosa tenuiflora, Ilex paraguariensis, Ocotea odorífera, Hymenaea courbaril, and Schinus terebinthifolia (Gonçalves et al., 2005), and Cymbopogon citratus (Schuck et al., 2001). Species tested whose leaves showed no inhibitory activity included Genipa americana, Tabebuia avellanedae, Casearia sylvestris, Pterodon emarginatus, Copaifera langsdorffii., Anadenanthera colubrine, and Myroxylon peruiferums (Gonçalves et al., 2005) and mango peels (Oliveira et al., 2011).

Ethanol extracts presented in this study showed activity against all microorganisms tested with effects more or less pronounced according to the microorganism studied. This may have occurred due to $B$. anisandra having alkaloids, flavonoids, anthraquinones, saponins and tannins in leaves (Frias et al., 2011), substances reported in the literature as showing different biological activities, including antimicrobial activity (Rodriguez et al., 2011).

Additional studies are needed to evaluate the interference of the season in the efficiency of extracts against the microorganisms used in this work and also to evaluate the efficiency of extracts against other pathogens or their resistance to usual antibiotics. The search for subfractions in each of the extracts, re-extracted by other solvents, will identify specific elements with inhibitory capacity.

\section{CONCLUSION}

Given the results, we concluded that the ethanol extract prepared by decoction at 107.5 $\mathrm{mg} / \mathrm{mL}$ significantly inhibited the mycelia growth of Rizoctonia solani and more discreetly the growth of F. oxysporum. C. albicans and S. aureus showed high sensitivity to different concentrations of both extracts studied.

\section{REFERENCE}

AGUIAR, J.S. et al. Atividade antimicrobiana de Lippia alba (Mill.) N. E. brown (Verbenaceae). Revista Brasileira de Farmacognosia, v.18, n.3, p. 436-440, 2008.

ALVES, P.M. et al. Atividade antifúngica do extrato de Psidium guajava Linn (goiabeira) sobre leveduras do gênero Candida da cavidade oral: uma avaliação in vitro. Revista Brasileira de Farmacognosia, v.16, n.2, p. 192-196, 2006.

BAJPAI, V.K.; SHUKLA, S.; KANG, S.C. Chemical composition and antifungal activity of essential oil and various extract of Silene armeria L. Bioresource Technology, v.99, n.18, p. 8903-8908, 2008.

BAUER, A.W. et al. Antibiotic susceptibility testing by the standardized single disk method. American Journal of Clinical Pathology, v.45, n.4, p. 493-496, 1966.

BERTUCCI, A. Initial antimicrobial activity studies of plants of the riverside forests of the southern Uruguay River. Revista Brasileira de Farmacognosia, v.19, n.1, p. 20-25, 2009.

CALIXTO, J.B. Twenty-five years of research on medicinal plants in Latin America. A personal view. Journal of the Ethnopharmacology, v.100, n.1-2, p.131-134, 2005.

CLARK, T.A.; HAJJEH, R.A. Recent trends in the epidemiology of invasive mycoses. Current Opinion in Infectious Diseases, v.15, p.569-574, 2002.

COSTA, A.R.T. et al. Ação do óleo essencial de Syzygium aromaticum (L.) Merr. \& L.M. Perry sobre as hifas de alguns fungos fitopatogênicos. Revista Brasileira de Plantas Medicinais, v.13, n.2, p. 240-245, 2011.

CUNICO, M.M. et al. Contribuição ao estudo da atividade antifúngica de Maytenus ilicifolia Mart. Ex Reiss., Celastraceae. Revista Brasileira de Farmacognosia, v.12, n.2, p.69-73, 2002.

DAMBOLENA, J.S. et al. Essential oils composition of Ocimum basilicum L. and Ocimum gratissimum L. from Kenya and their inhibitory effects on growth and fumonisin production by Fusarium verticillioides. Innovat. Food Science \& Technology, v.11, n.2, p. 410-414, 2010.

DIAS, J.F.G. et al. Atividade antibacteriana e antifúngica de extratos etanólicos de Aster Lanceolatus Willd., Asteraceae. Revista Brasileira de Farmacognosia, v.16, n.1, p.83-87, 2006.

DIENSTMANN R. et al. J. Avaliação fenotípica da enzima Klebsiella pneumoniae 109 carbapenemase (KPC) em Enterobacteriaceae de ambiente hospitalar. Jornal Brasileiro de Patologia e Medicina Laboratorial, v.81, p.133-35, 2010.

FENILLE, R.C.; SOUZA, N. L. Efeitos de materiais orgânicos e da umidade do solo na patogenicidade de Rhizoctonia solani Kühn GA-4 HGI ao feijoeiro. Pesquisa Agropecuária Brasileira, v. 34, n.10, p.19591967, 1999.

FERREIRA, D. F. SISVAR: Um programa para análise e ensino de estatística. Revista Symposium, v. 6, p.36-4, 2008.

FREITAS, L.B. de OLIVEIRA. Estudo fitoquímico e da atividade biológica de Banisteriopsis anisandra (A. Juss) B. Gates e síntese de amidas indólicas para avaliação da atividade alelopática. 2010. 163 p. Dissertação (Mestrado em Química - Química Orgânica) - Departamento de Química, Universidade Federal de Minas Gerais, Belo Horizonte.

FRIAS, U.A. de; MENDES-COSTA, M.C, TAKAHASHI, J.A. Caracterización fitoquímica y de las actividades antibacterianas y anticolinesterasa de Banisteriopsis anisandra A. Juss. (Malpighiaceae). Revista Cubana de Plantas Medicinales, v.16, n.1, p. 60-71, 2011.

GONÇALVES, A.L.; ALVES FILHO, A.; MENEZES, H. Estudo comparativo da atividade antimicrobiana de extratos de algumas árvores nativas. Arquivos do Instituto Biológico, v.72, n.3, p. 353-358, 2005.

GOULART, A.C.P. Doenças iniciais do algodoeiro identificação e controle. In: ZAMBOLIM, L. (Ed.). Sementes: qualidade fitossanitária. Viçosa, MG: Universidade Federal de Viçosa, 2005. p. 425-449.

GOULART, A.C.P. Efeito do Tratamento de Sementes de

Rev. Bras. PI. Med., Campinas, v.15, n.3, p.431-437, 2013. 
Algodoeiro com Fungicidas no Controle do Tombamento de Plântulas e da Mela Causados por Rhizoctonia solani. Boletim de Pesquisa e desenvolvimento. Dourados, MS, 2008. 25 p.

HEINEMANN, J.A., ANKENBAUER, R.G., AMÁBILECUEVAS, C.F. Do antibiotics maintain antibiotic resistance? Drug Discovery Today, v.5, n.5, p.195204, 2000.

HELMERHORST, E.J. et al. Amphotericin B- and fluconazole-resistant Candida spp., Aspergillus fumigatus, and other newly emerging pathogenic fungi are susceptible to basic antifungal peptides. Antimicrobial Agents and Chemotherapy, v.43, n.3, p. 702-704, 1999.

KIRCHNER, K. et al. Chemical composition and antimicrobial activity of Hedyosmum brasiliense Miq., Chloranthaceae, essential oil. Revista Brasileira de Farmacognosia, v.20, n.5, p. 692-699, 2010.

MAGUIRE, J.D. Speed of germination-aid in selection and evaluation for seedling emergence and vigours. Crop Science, v.2, n.2, p. 176-177, 1962.

OLIVEIRA, J.A. Efeito do tratamento fungicida em sementes e no controle de tratamento de plântulas de pepino (Cucumis sativus L.) e pimentão (Capsicum annuum L.). 1991. 111 f. Dissertação (Mestrado em Fitopatologia) - Escola Superior de Agricultura de Lavras, Lavras.

OLIVEIRA, S.M.S. de et al. Modulation of drug resistance in Staphylococcus aureus by extract of mago (Mangifera indica) peel. Revista Brasileira de Farmacognosia, v.21, n.1, p. 190-193, 2011.

REGASINI, L.O. Trypanocidal activity of Piper arboreum and Piper tuberculatum (Piperaceae). Revista Brasileira de Farmacognosia, v.19, n.1, p. 199-203, 2009.

RODRIGUES, V.E.G.; CARVALHO, D.A. de. Levantamento etnobotânico de plantas medicinais no domínio Cerrado na região do Alto Rio Grande - Minas Gerais. Ciência e Agrotecnologia, v.25, n.1, p. 102-123, 2001.

RODRIGUEZ, L.D.D.C.et al. Tamizaje fitoquímico y actividad antibacteriana de extractos de Bryophyllum pinnata. Revista Química Viva, v.10, n.1, 2011.

ROSSI, F. The challenges of antimicrobial resistance in Brazil. Clinical Infectious Diseases, v.52, n.9, p.113843, 2011.

SAMOYLENKO, V. et al. Banisteriopsis caapi, a unique combination of MAO inhibitory and antioxidative constituents for the activities relevant to neurodegenerative disorders and Parkinson's disease. Journal of Ethnopharmacology, v.127, n.2, p. 357-367, 2010.

SCHUCK, V.J.A. et al. Avaliação da atividade antimicrobiana de Cymbopogon citratus. Revista Brasileira de Ciências Farmacêuticas, v.37, n.1, p. 45-49, 2001.

SHINOBU-MESQUITA, C.S. et al. Antifungal activity of the extract of Curcuma zedoaria (Christm.) Roscoe, Zigiberaceae, against yeasts of the genus Candida isolated from the oral cavity of patients infected with the human immunodeficiency virus. Revista Brasileira de Farmacognosia, v.21, n.1, p.128-132, 2011.

SILVA, I.D. da et al. Efeito do extrato de sucupira (Pterodon emarginatus Vog.) sobre o desenvolvimento de fungos e bactérias fitopatogenicos. Pesquisa Agropecuária Tropical, v.35, n.2, p.109-115, 2005.

STEFANELLO, M.E.A. et al. Avaliação da atividade antimicrobiana e citotóxica de extratos de Gochnatia polymorpha ssp floccosa. Revista Brasileira de Farmacognosia, v.16, n.4, p. 525-530, 2006.

WORLD HEATLH ORGANIZATION. (2010) WHO Health, Geneve: Site do WHO, http://www.who.int/en acess june 2011.

Rev. Bras. PI. Med., Campinas, v.15, n.3, p.431-437, 2013. 